\title{
Assessment on the prevalence and risk factors of gastrointestinal parasites on schoolchildren at Bochesa Elementary School, around Lake Zwai, Ethiopia
}

\author{
Ayalew Sisay ${ }^{1 *}$ and Brook Lemma ${ }^{2}$
}

\begin{abstract}
Objectives: This study was aimed to assess the prevalence and risk factors of gastrointestinal parasites on schoolchildren at Bochesa Elementary School around Lake Zwai, Ethiopia. Cross-sectional study was conducted on 384 schoolchildren in May 2016. The gastrointestinal parasites were examined with wet mount and formol-ether concentration techniques. Chi-square $\left(x^{2}\right)$ test was used to evaluate the association between categorical variables and infection prevalence. Binary logistic regression on SPSS version 21 was used, values were considered significant when the $p$-value was less than 0.05 .

Results: The overall prevalence of gastrointestinal parasites was 22.6\%. Males, 54 (14.1\%) were more infected than females, 32 (8.3\%), and 1-4 grade category, 64 (16.7\%) were more infected than 5-8 grade category, 22 (5.7\%). Age groups of 7-14, 78 (20.3\%) were also more infected than $>15,8$ (2.1\%); however, the variation was not significant $(p>0.05)$. In this study, parasitic coinfection was common; however, single gastrointestinal parasites were more dominant. The overall rate of gastrointestinal parasites shows that the environmental conditions where students pass their times are conducive to water-related diseases. Health education on personal and environmental hygiene keeping should be given to schoolchildren and safe wetland playing grounds should be prepared.
\end{abstract}

Keywords: Children, Lake Zwai, Gastrointestinal, Parasites, Wetlands

\section{Introduction}

Many civilizations have been built on the basis of wetland resources [1]; this indicates that wetlands and people are ultimately interdependent with each other $[2,3]$. In developing countries, the livelihoods of people are intimately linked with wetlands and these interactions lead to the emergence of gastrointestinal parasitic infections [4].

Faecal-oral contact of infective parasitic stages is important route to human infection by water-related gastrointestinal parasites [5, 6]. Factors like eating raw vegetables, lack of hygiene, unsafe drinking water, lack

\footnotetext{
*Correspondence: ayalewsisay@gmail.com

${ }^{1}$ Department of Biology, College of Natural Science, Debre Markos

University, P. O. Box 269, Debre Markos, Ethiopia
}

Full list of author information is available at the end of the article of toilet facilities, walking barefoot, fishing, irrigation, swimming, playing with moist soil and open defecation may increase the prevalence of gastrointestinal parasites [7] of wetland areas.

The prevalence of gastrointestinal parasites varies from region to region [7]. Prevalence of gastrointestinal parasites has been studied in different countries including Ethiopia [7, 8]. It was found out that these diseases are more prevalent on school age children [9-11]. Hence, the present study was aimed at assessing the prevalence and risk factors of gastrointestinal parasitic infections on schoolchildren at a school located in close proximity to the wetlands of Lake Zwai. 


\section{Main text \\ Methods}

\section{Study setting and period}

Cross-sectional study was conducted in May 2016 on Bochesa Elementary schoolchildren around Lake Zwai, which is located in the Southwestern direction of lake Zwai, about $167 \mathrm{~km}$ South of Addis Ababa, which is the capital of Ethiopia. The school is situated at an altitude of $1636 \mathrm{~m}$ above sea level, which is similar to the lake. Students of the school are living under poor socio-economic status and with no adequate safe water supply in their village; and their parents lead their life by cultivation of maize and vegetables using lake water for irrigation and rearing of livestock.

\section{Sample size and sampling techniques}

The desired sample size (n) required for the assessment of gastrointestinal parasites and associated risk factors was estimated using standard formula [12].

$$
\mathrm{n}=\frac{\left(z^{2} p(1-p)\right)}{d^{2}}
$$

where $\mathrm{n}$ is sample size, $\mathrm{z}$ is 1.96 , which is $\mathrm{z}$ statistics level of confidence, $\mathrm{d}=0.05$ (absolute precision), and $\mathrm{p}=$ expected prevalence of the area.

Since the prevalence of gastrointestinal parasites is not known for this study area on schoolchildren, $p$-value was taken to be $50 \%$. A $95 \%$ confidence interval $(\mathrm{z})$ and a $5 \%$ margin of error (d) was used. Therefore, 384 (192 males and 192 were females) students from 7 to 25 years were involved.

\section{Laboratory investigations}

Stool samples were collected using applicator sticks in a labeled plastic container.

About $5 \mathrm{~g}$ of fresh fecal samples were collected from each students and placed in separate labeled clean plastic stool containers. A small portion of about $2 \mathrm{~g}$ sample from each student was examined using wet mount and the remaining about $3 \mathrm{~g}$ sample was examined using formol-ether concentration technique [13]. The overall presence of gastrointestinal parasites was confirmed when observed by any of the methods used.

\section{Questionnaire administration}

A questionnaire was developed in English and translated into Afan Oromo (the local language) to collect socio demographic data, environmental factors and behavioral habits.

\section{Statistical analysis}

The prevalence of infections was reported in proportions. Chi-square $\left(x^{2}\right)$ test was used to evaluate the association between categorical variables and prevalence. For identification of determinant factors, Binary logistic regression was used, and finally the association between independent variables and dependent variables were described on the basis of odd ratio (OR) with 95\% confidence interval (CI). Crude OR was estimated by univariate regression analysis and adjusted OR was then estimated by multivariate logistic regression analysis. Values were considered statistically significant when the $p$-value was less than 0.05 .

\section{Results}

The overall prevalence of gastrointestinal parasites infection was $22.4 \%$ (95\% CI 18-26.3\%). Different types of parasites like cestodes, nematodes and protozoans with a value of $37(9.6 \%), 40(10.4 \%)$ and 29 (7.6\%) were identified, respectively from Bochesa Elementary School students. Of these eight species identified, Hymenolepis nana was the predominant parasites detected on 34 (8.9\%), and least prevalence was recorded on Taenia spp. with a value of $3(0.8 \%)$ (Table 1).

The prevalence of gastrointestinal parasites was statistically significant $\left(X^{2}=7.252 ; p=0.005\right.$ and $\left.\chi^{2}=6.177 ; p=0.008\right)$ between sex and grade categories, respectively; whereas insignificant $(p>0.05)$ variations was observed on the prevalence of gastrointestinal parasites between age groups.

Of these $86(22.4 \%)$ positive cases, infection with single parasite was more dominant (14.8\%) than mixed infections, in which double, triple and quadruple parasitic infections with a value of $6.0 \%, 1.3 \%$ and $0.3 \%$, respectively (Fig. 1). The prevalence of single parasitic infection was statistically significant $\left(\chi^{2}=4.635\right.$; $p=0.022)$ between se; whereas insignificant $(p>0.05)$ variations were observed with age and grade category.

Table 1 Different species of gastrointestinal parasites and their prevalence on Bochesa Elementary School

\begin{tabular}{llcl}
\hline Parasites & Species obtained & Frequency & Prevalence (\%) \\
\hline Nematodes & A. lumbricoides & 17 & 4.43 \\
& T. trichuria & 8 & 2.08 \\
& S. stercoralis & 8 & 2.08 \\
& Hookworm spp. & 14 & 3.65 \\
Cestodes & H. nana & 34 & 8.85 \\
& Taenia spp. & 3 & 0.78 \\
Protozoa & E. histolytica/dispar & 20 & 5.21 \\
& G. lamblia & 18 & 4.69 \\
\hline
\end{tabular}




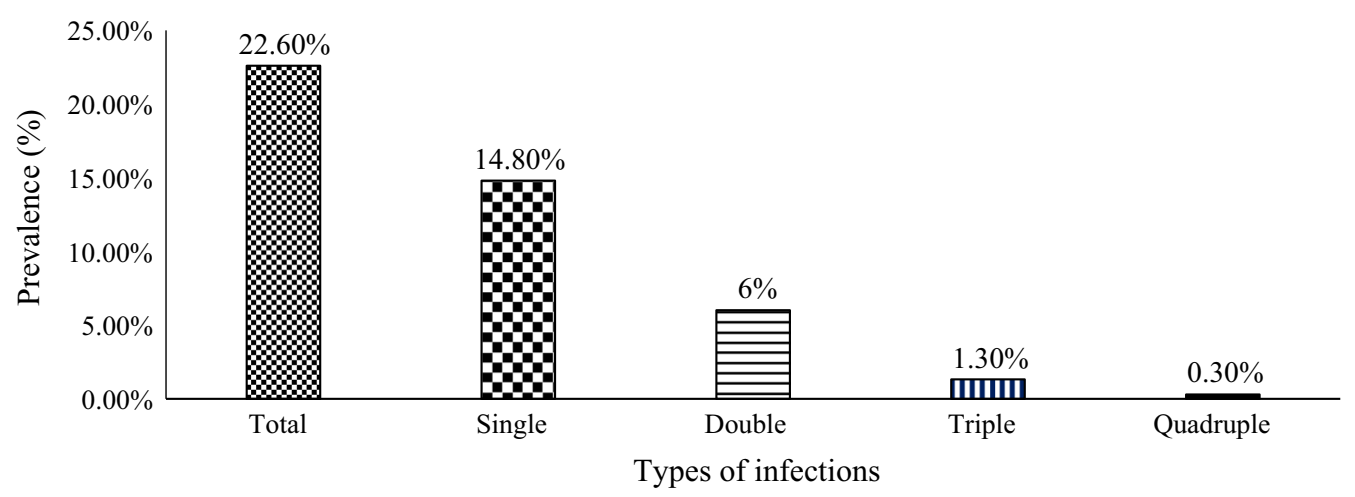

Fig. 1 Prevalence of single and mixed parasitic infections among Bochesa Elementary School students

\section{Potential risk factors associated with gastrointestinal parasites}

Being male increases the risk of gastrointestinal parasite infection 7.79-folds than being female (AOR: 7.799: 95\% CI 1.948-31.222). Students who were from 5 to 8 grade category decreases the risk of gastrointestinal parasite infection by $69.3 \%$ than students from 1 to 4 grade category (AOR: 0.307: CI 95\% 0.110-0.855). Students who had fishing habits were 3.027 times more likely to be infected by gastrointestinal parasites than their counter parts (AOR: 3.027: CI 95\% 1.117-8.206). Students who had raw meat-eating habits were 4.710 times more likely to be infected by gastrointestinal parasites than students who didn't eat raw meat (AOR: 4.710: CI 95\% 1.626-13.643). Similarly, students who had raw vegetable eating habit were 2.8 times more likely to be infected by gastrointestinal parasites than their counter parts (AOR: 2.800: CI 95\% 1.126-6.961). Students who had habits of playing with moist soil were 8.571 -folds increases the risk of gastrointestinal parasites than students who didn't play (AOR: 8.571: CI 95\% 3.884-18.913). Similarly, students who had sometimes hand washing habit before meals were 4.961 -folds increased the risk of gastrointestinal parasites than students who washed their hands before meals (AOR: 4.961: CI 95\% 1.773-13.879). Students who practiced open defecation showed increased the risk of gastrointestinal parasite infections with a rate of 6.12 times more than students who used latrines (AOR: 6.118: CI 95\% 2.414-15.510) (Table 2).

\section{Discussion}

The present study revealed the occurrence of eight species of gastrointestinal parasite on schoolchildren. The overall prevalence (22.4\%) of gastrointestinal parasites observed in this study is comparable with reported cases of Ethiopia [14] and Angola [15].
The present result is also lower when compared with other earlier reports from different parts of the country $[7,9,16,17]$, and outside (Turkey [18] and Egypt [19]). The probable reason for this variation might be attributed to the variation in environmental and living conditions of the study participants.

The occurrence of gastrointestinal helminth parasitic infections among students of Bochesa Elementary School found in Zwai wetlands is an indication of faecal contamination of soil, improper utilization of latrines or absence of them and poor personal hygiene in the area. Similar finding was reported in Zwai Town on pregnant woman [20].

In this study, $H$. nana (8.9\%) was the dominant parasite. Similar findings were reported inside the country $[21,22]$. The observed prevalence of $8.6 \%$ for $H$. nana in this study was in agreement with different researchers inside the country [8, 23, 24]; and in Burkina Faso [25]. This result was also relatively higher compared to other studies in different areas of the country [26-31]. This difference might be due to the variation in environmental and living conditions of the study participants.

Higher prevalence of gastrointestinal parasites on males in this study was supported by different researchers inside the country $[8,12,22,23]$ and elsewhere [32, 33]. The probable reason for this variation might be due to more involvement of males in outdoor activities. These activities sometimes carried out bare-footed and this situation predisposing males to infections.

Similarly, higher prevalence of gastrointestinal parasites on lower age groups was in agreement with other reports inside the country [29, 34-36], and Bangalore [37]. The probable reason for this difference might be due to frequent contact and the habit of inserting soil contaminated fingers to their mouth and less awareness of hand washing practices may increase the chance of acquiring gastrointestinal parasites in lower age groups. 
Table 2 Binary logistic regression analysis for factors potentially associated with gastro intestinal parasite infection among Bochesa Elementary Schoolchildren

\begin{tabular}{|c|c|c|c|c|}
\hline Risk factors & Category & Positive (\%) & Negative (\%) & Adjusted OR $(95 \% \mathrm{Cl})$ \\
\hline \multirow[t]{2}{*}{ Sex } & Male & 51 & 141 & $7.779 *(1.948-31.222)$ \\
\hline & Female & 32 & 160 & \\
\hline \multirow[t]{2}{*}{ Grade category } & $1-4$ & 61 & 181 & $0.307^{*}(0.110-0.855)$ \\
\hline & $5-8$ & 22 & 120 & \\
\hline \multirow[t]{2}{*}{ Fishing habit } & Yes & 53 & 117 & $3.027^{*}(1.117-8.206)$ \\
\hline & No & 30 & 184 & \\
\hline \multirow[t]{2}{*}{ Raw meat-eating } & Yes & 63 & 165 & $4.710 *(1.626-13.643)$ \\
\hline & No & 20 & 136 & \\
\hline \multirow[t]{2}{*}{ Playing with moist soil } & Yes & 36 & 34 & $8.571^{*}(3.884-18.913)$ \\
\hline & No & 47 & 267 & \\
\hline \multirow[t]{2}{*}{ Water for bathing } & Lake water & 79 & 255 & $2.125(0.720-6.274)$ \\
\hline & Ground water & 4 & 46 & \\
\hline \multirow[t]{2}{*}{ Raw vegetable eating } & Yes & 47 & 88 & $2.800 *(1.126-6.961)$ \\
\hline & No & 36 & 213 & \\
\hline \multirow[t]{2}{*}{ Hand washing } & Sometimes & 27 & 13 & $4.961 *(1.773-13.879)$ \\
\hline & Yes & 56 & 288 & \\
\hline \multirow[t]{2}{*}{ Finger nail trimming } & Yes & 32 & 200 & \\
\hline & No & 51 & 101 & $1.869(0.801-4.361)$ \\
\hline \multirow[t]{2}{*}{ Area of defecation } & Latrine & 9 & 151 & \\
\hline & Open defecation & 74 & 150 & $6.118^{*}(2.414-15.510)$ \\
\hline \multirow[t]{2}{*}{ Shoe wearing habit } & Yes & 27 & 190 & $2.109(0.852-5.220)$ \\
\hline & No & 56 & 111 & \\
\hline
\end{tabular}

*Significant association

Higher prevalence of gastrointestinal parasites on 1-4 grade category was also inline with other studies in Ethiopia $[21,29,34]$. The probable reason for this variation might be due to awareness created to improve personal hygiene in 5-8 grades. The present study revealed that the existence of parasitic co-infection in the wetland of Lake Zwai in Bochesa Elementary schoolchildren. In line with this findings, parasitic co-infections were reported inside the country $[7,9,16,29,38]$.

The possible reason for the existence of parasitic coinfections in the study area might be associated with Zwai wetland, which is found in front of their residences to make frequent contact for swimming, bathing, fishing and irrigation purpose in the lake and the wetlands around it. In this study, single parasitic infections were more common than parasitic co-infections. These results were comparable with studies conducted elsewhere in Ethiopia $[9,16,17,21,30]$.

The present study shows that the likelihood of acquiring gastrointestinal parasites in males was 7.79 times higher than in females. In accordance with these findings, agricultural and fishing areas at the lake borders and irrigation canals are common defecation places by males during working times, facilitating the transmission of gastrointestinal parasites would be facilitated. Similar findings were reported in studies conducted elsewhere in Ethiopia [14, 22].

Students having raw-meat eating habits were 4.71 times more likely to be infected by gastrointestinal parasites such as Taenia spp. than students who had no raw-meat eating habits. Recently, the custom of eating raw-meat has grown worldwide in ethnic groups where eating raw-meat was not previously common [5].

Students who had raw vegetable-eating habit were 2.80 times more likely to acquire gastrointestinal parasites than students who had no raw vegetable-eating habits. This finding was supported by studies in Ethiopia [39-42].

Students who played with moist soil were 8.57 times more likely to be infected by gastrointestinal parasites than students who had no such habits. This might be due to the fact that moist soil creates an environment conducive for a high prevalence of intestinal parasites $[43,44]$.

Students who have practiced open defecation were 6.12 times more likely to acquire gastrointestinal parasites than those who used latrines. Similar findings were reported $[8,27,41]$. 


\section{Conclusion}

The study revealed that the wetland of Lake Zwai are conducive for the survival of water-related gastrointestinal parasites as observed in the schoolchildren of the area. As the weather condition of Zwai wetlands is hot and humid coupled with wet soil is a suitable environment for the occurrence of infective stages of gastrointestinal parasites. These disposing factors to the disease is further increased due to the poor economic status of the community of the area and the nature of students who do not see the risks of infection by gastrointestinal parasites that are out there.

\section{Limitations}

We used only wet mount and formol-ether concentration technique to assess the prevalence of gastrointestinal parasites in the collected samples.

\section{Acknowledgements}

The authors would like to thank to the Water Thematic Research Project of Addis Ababa University for financially supporting this project, and Adami Tulu Agricultural and Zwai Fisheries Research Centers for allow us access to their laboratory facilities.

\section{Authors' contributions}

$\mathrm{AS}$ and $\mathrm{BL}$ have designed the proposal, data collection, data analysis, interpretation and later developed this manuscript. Both authors read and approved the final manuscript.

\section{Funding}

No funding organization was involved as a grant for this study.

\section{Availability of data and materials}

The data used and analyzed in this study are available from the corresponding author on reasonable request.

\section{Ethics approval and consent to participate}

Prior to stool collection, a formal letter request of cooperation was submitted to the Adami Tulu Jido Kombolcha Woreda Health Office at Zwai town and the school principal of Bochesa Elementary School. The ethical approval committee of Adami Tulu Jido Kombolcha Woreda Health Office has approved the request. Accordingly, the necessary permissions were obtained from each student, their families and finally, appropriate treatment was given to students who were found positive for gastrointestinal parasites by local nurses. For students who are under the age of 18 , parents signature was prepared to be signed through the questionnaire.

\section{Consent for publication}

This is not applicable, since any photographs or videos were not taken.

\section{Competing interests}

The authors declare that they have no competing interests.

\section{Author details}

1 Department of Biology, College of Natural Science, Debre Markos University, P. O. Box 269, Debre Markos, Ethiopia. ${ }^{2}$ Department of Zoology, College of Natural Science, Addis Ababa University, P. O. Box 1176, Addis Ababa, Ethiopia.

Received: 3 April 2019 Accepted: 5 July 2019

Published online: 15 July 2019
References

1. Shine C, De Klemm C. Wetlands, water, and the law: using law to advance wetland conservation and wise use. London: IUCN; 1999.

2. Brouwer J, Abdoul Kader HA, Sommerhalter T. Wetlands help maintain wetland and dryland biodiversity in the Sahel, but that role is under threat: an example from 80 years of changes at Lake Tabalak in Niger. Biodiversity. 2014;15(2-3):203-19.

3. Kansiime F, Saunders MJ, Loiselle SA. Functioning and dynamics of wetland vegetation of Lake Victoria: an overview. Wetl Ecol Manag. 2007;15(6):443-51.

4. Hailu T. Current prevalence of intestinal parasites emphasis on hookworm and Schistosoma mansoni infections among patients at Workmeda Health Center. Northwest Ethiopia. Clin Microbiol Open Access. 2014;3(4):1-4.

5. Macpherson CN. Human behaviour and the epidemiology of parasitic zoonoses. Int J Parasitol. 2005;35(11-12):1319-31.

6. Ekong PS, Juryit R, Dika NM, Nguku P, Musenero M. Prevalence and risk factors for zoonotic helminth infection among humans and animals, Jos Nigeria, 2005-2009. Pan Afr Med J. 2012;12(1):1-6.

7. Legesse M, Erko B. Prevalence of intestinal parasites among schoolchildren in a rural area close to the southeast of Lake Langano, Ethiopia. Ethiop J Health Dev. 2004;18(116):120.

8. Haile A, Abera T, Dana D. The prevalence of intestinal parasitic infection and associated factors among primary school children in Gurage zone, South. J Pharm Altern Med. 2016;15:8-15.

9. Hailegebriel T. Undernutrition, intestinal parasitic infection and associated risk factors among selected primary school children in Bahir Dar, Ethiopia. BMC Infect Dis. 2018;18(1):394.

10. Cook DM, Swanson RC, Eggett DL, Booth GM. A retrospective analysis of prevalence of gastrointestinal parasites among school children in the Palajunoj Valley of Guatemala. J Health Popul Nutr. 2009;27(1):31.

11. Omalu IC, Agu N, Ejima IA, Pam DD, Adeniyi KA, Eke SS, Otuu CA, Nnaji Cl, Garba Y, Zhiri VG, Makinde HA. Epidemiology of gastrointestinal parasites among school children in Minna, Niger State, Nigeria. Ann Biomed Sci. 2017;16(1):225-35.

12. Daniel WW. Biostatistics: a foundation for analysis in the health sciences. 6th ed. New York: Wiley; 1995.

13. Cheesbrough M. District laboratory practice in tropical countries. Cambridge: Cambridge University Press; 2006.

14. Tulu B, Taye S, Amsalu E. Prevalence and its associated risk factors of intestinal parasitic infections among Yadot primary school children of South Eastern Ethiopia: a cross-sectional study. BMC Res Notes. 2014;7(1):848.

15. de Alegría ML, Colmenares K, Espasa M, Amor A, Lopez I, Nindia A, Kanjala J, Guilherme D, Sulleiro E, Barriga B, Gil E. Prevalence of Strongyloides stercoralis and other intestinal parasite infections in school children in a rural area of Angola: a cross-sectional study. Am J Trop Med Hyg. 2017;97(4):1226-31.

16. Abossie A, Seid M. Assessment of the prevalence of intestinal parasitosis and associated risk factors among primary school children in Chencha town, Southern Ethiopia. BMC Public Health. 2014;14(1):166.

17. Workneh T, Esmael A, Ayichiluhm M. Prevalence of intestinal parasitic infections and associated factors among Debre Elias primary school's children, East Gojjam Zone, Amhara Region, North West Ethiopia. J Bacteriol Parasitol. 2014;5(1):1.

18. Doni NY, Gurses G, Simsek Z, Zeyrek FY. Prevalence and associated risk factors of intestinal parasites among children of farm workers in the southeastern Anatoliana regions of Turkey. Ann Agric Environ Med. 2015;20(1):438-42.

19. El-sehry NM, Fouda LM, Hassan LWA. Prevalence of parasitic infections and its effect on the health status of primary school children. IOSR J Nurs Health Sci. 2017;6(4):41-52.

20. Tefera G. Determinants of anemia in pregnant women with emphasis on intestinal helminthic infection at Sher-Ethiopia Hospital, Ziway, Southern Ethiopia. Immunol Infect Dis. 2014:2(4):33-9.

21. Gelaw A, Anagaw B, Nigussie B, Silesh B, Yirga A, Alem M, Endris M, Gelaw B. Prevalence of intestinal parasitic infections and risk factors among schoolchildren at the University of Gondar Community School, Northwest Ethiopia: a cross-sectional study. BMC Public Health. 2013;13(1):304.

22. Tefera E, Mohammed J, Mitiku H. Intestinal helminthic infections among elementary students of Babile town, eastern Ethiopia. Pan Afr Med J. 2015:20(1):1-10. 
23. Endris M, Lemma W, Belyhun Y, Moges B, Gelaw A, Angaw B. Prevalence of intestinal parasites and associated risk factors among students of Atse Fasil general elementary school Azezo, Northwestern Ethiopia. Ethiop J Health Biomed Sci. 2010;3(1):25-33.

24. Teklemariam A, Dejenie T, Tomass Z. Infection prevalence of intestinal helminths and associated risk factors among schoolchildren in selected kebeles of Enderta district, Tigray, Northern Ethiopia. J Parasitol Vector Biol. 2014;6(11):166-73.

25. Erismann S, Diagbouga S, Odermatt P, Knoblauch AM, Gerold J, Shrestha A, Grissoum T, Kaboré A, Schindler C, Utzinger J, Cissé G. Prevalence of intestinal parasitic infections and associated risk factors among schoolchildren in the Plateau Central and Centre-Ouest regions of Burkina Faso. Parasites Vectors. 2016;9(1):554.

26. Haftu D, Deyessa N, Agedew E. Prevalence and determinant factors of intestinal parasites among school children in Arba Minch town, Southern Ethiopia. Am J Health Res. 2014;2(5):247-4.

27. Kidane E, Menkir S, Kebede A, Desta M. Prevalence of intestinal parasitic infections and their associations with anthropometric measurements of school children in selected primary schools, Wukro Town, Eastern Tigray, Ethiopia. Sci J Zool. 2013;229(1319):1-6.

28. Wale M, Wale M, Fekensa T. The prevalence of intestinal helminthic infections and associated risk factors among school children in Lumame town Northwest, Ethiopia. J Parasitol Vector Biol. 2014;6(10):156-65.

29. Gebretsadik G. Prevalence of intestinal parasites and associated risk factors among schoolchildren of Homesha district (Woreda) in BenishangulGumuz regional state, western Ethiopia. J Fam Med Health Care. 2016;2(4):57-64

30. Abdi M, Nibret E, Munshea A. Prevalence of intestinal helminthic infections and malnutrition among schoolchildren of the Zegie Peninsula, northwestern Ethiopia. J Infect Public Health. 2017;10(1):84-92.

31. Lone R, Syed K, Lone A. Recent patterns and risk factors of intestinal helminthes infection among school children in Kashmir, India. Arch Clin Microbiol. 2011;2(3):1-4.

32. Albonico M, Chwaya HM, Montresor A, Stolfzfus RJ, Tielsch JM, Alawi KS, Savioli L. Parasitic infections in Pemba Island school children. East Afr Med J. 1997;74(5):294-8.

33. Baral $R$, Jha $P$, Amatya $R$, Khanal B. Prevalence of intestinal parasitic infections among patients attending in a tertiary care hospital of eastern region of Nepal. A retrospective, laboratory based study. Asian J Med Sci. 2017:8(3):55-9.
34. Meles W, Merid I, Asfaw M. A study of the incidence of intestinal helminthic diseases and their risk factors among school Children in Lumame town, Northwest, Ethiopia. Afr J Parasitol Res. 2015;2(10):152-60.

35. Norris J, Adelman C, Spantchak Y, Marano K. Social and economic impact review on neglected tropical diseases. Economic Policy/Briefing Paper. Washington DC: Hudson Institute; 2012.

36. Nyantekyi LA, Legesse M, Belay M, Tadesse K, Manaye K, Macias C, Erko $B$. Intestinal parasitic infections among under-five children and maternal awareness about the infection in Shesha Kebele, Wondo Genet, Southern Ethiopia. Ethiop J Health Dev. 2010;24(3):185-90.

37. Golia S, Sangeetha KT, Vasudha CL. Prevalence of parasitic infections among primary school children in Bangalore. Int J Basic Appl Med Sci. 2014:4(1):356-61.

38. Ayalew A, Debebe T, Worku A. Prevalence and risk factors of intestinal parasites among Delgi school children, North Gondar, Ethiopia. J Parasitol Vector Biol. 2011;3(5):75-81.

39. Alamir M, Awoke W, Feleke A. Intestinal parasites infection and associated factors among school children in Dagi primary school, Amhara National Regional State, Ethiopia. Health. 2013;5(10):1697.

40. Alemu A, Atnafu A, Addis Z, Shiferaw Y, Teklu T, Mathewos B, Birhan W Gebretsadik S, Gelaw B. Soil transmitted helminths and Schistosoma mansoni infections among school children in Zarima town, northwest Ethiopia. BMC Infect Dis. 2011;11(1):189.

41. Abera A, Nibret E. Prevalence of gastrointestinal helminthic infections and associated risk factors among schoolchildren in Tilili town, northwest Ethiopia. Asian Pac J Trop Med. 2014;7(7):525-30.

42. Alelign T, Degarege A, Erko B. Soil-transmitted helminth infections and associated risk factors among schoolchildren in Durbete Town, Northwestern Ethiopia. J Parasitol Res. 2015:2015:641602.

43. Abera B, Alem G, Yimer M, Herrador Z. Epidemiology of soil-transmitted helminths, Schistosoma mansoni, and haematocrit values among schoolchildren in Ethiopia. J Infect Dev Ctries. 2013;7(03):253-60.

44. Feleke BE. Nutritional status and intestinal parasite in school age children: a comparative cross-sectional study. Int J Pediatr. 2016;2016:1962128.

\section{Publisher's Note}

Springer Nature remains neutral with regard to jurisdictional claims in published maps and institutional affiliations.
Ready to submit your research? Choose BMC and benefit from:

- fast, convenient online submission

- thorough peer review by experienced researchers in your field

- rapid publication on acceptance

- support for research data, including large and complex data types

- gold Open Access which fosters wider collaboration and increased citations

- maximum visibility for your research: over $100 \mathrm{M}$ website views per year

At BMC, research is always in progress.

Learn more biomedcentral.com/submissions 